\title{
ARTICLE
}

\section{Genes homologous to the autosomal dominant polycystic kidney disease genes (PKD1 and PKD2)}

\author{
Barbera Veldhuisen, Lia Spruit, Hans G Dauwerse, Martijn H Breuning and \\ Dorien JM Peters
}

MGC Department of Human and Clinical Genetics, Leiden University Medical Center, The Netherlands

\begin{abstract}
Autosomal Dominant Polycystic Kidney Disease (ADPKD), a common inherited disease leading to progressive renal failure, can be caused by a mutation in either the PKD1 or PKD2 gene. Both genes encode for putative transmembrane proteins, polycystin-1 and polycystin-2, which show significant homology to each other and are believed to interact at their carboxy termini. To identify genes that code for related proteins we searched for homologous sequences in several databases and identified one partial $\mathrm{CDNA}$ and two genomic sequences with significant homology to both polycystin-1 and - 2. Further analysis revealed one novel gene, $P K D 2 L 2$, located on chromosome band 5q31, and two recently described genes, $P K D 2 L$ and $P K D R E J$, located on chromosome bands $10 q 31$ and $22 q 13.3$, respectively. $P K D 2 L 2$ and $P K D 2 L$, which encode proteins of 613 and 805 amino acids, are approximately $65 \%$ similar to polycystin-2. The third gene, $P K D R E J$, encodes a putative 2253 amino acid protein and shows about $35 \%$ similarity to both polycystin-1 and polycystin-2. For all the genes expression was found in testis. Additional expression of PKD2L was observed in retina, brain, liver and spleen by RT-PCR. Analyses of five ADPKD families without clear linkage to either the PKD1 or $P K D 2$ locus showed no linkage to any of the novel loci, excluding these genes as the cause of ADPKD in these families. Although these genes may not be involved in renal cystic diseases, their striking homology to $P K D 2$ and $P K D 1$ implies similar roles and may contribute to elucidating the function of both polycystin-1 and polycystin-2.
\end{abstract}

Keywords: ADPKD; autosomal dominant polycystic kidney disease; polycystin; PKD1; PKD2; PKD2L; PKD2L2; PKDREJ

Correspondence: should be addressed to DJM Peters, MGC Department of Human and Clinical Genetics, Sylvius Laboratory, Wassenaarseweg 72, 2333 AL Leiden, The Netherlands. Tel: 3171 5276048; Fax: 3171 5276075; E-mail: d.peters@ruly46.medfac.leidenuniv.nl

Received 25 March 1999; revised 8 June 1999; accepted 18 June 1999 


\section{Introduction}

Polycystin-1 and polycystin-2, proteins encoded by the $P K D 1$ and $P K D 2$ genes, are mutated in the majority of patients with autosomal dominant polycystic kidney disease (ADPKD) ${ }^{1,2}$ The function of both proteins is still unclear. The PKD1 gene, located on chromosome band 16p13.3, encodes a putative protein of 4302 amino acids. $^{3-5}$ Most of the gene is reiterated several times more proximal on chromosome 16p. This homologous region encodes three large transcripts, but it is not known whether these transcripts produce functional proteins. ${ }^{4}$ Polycystin- 1 is predicted to be a transmembrane protein, with a long extracellular tail, 11 transmembrane domains and an intracellular carboxy terminus. ${ }^{6}$ The extracellular amino terminal part of polycystin-1 contains several domains, including 16 PKD domains ${ }^{4,5,7}$ and a REJ domain (receptor for egg jelly), ${ }^{6,8}$ which can be involved in protein-protein or protein-carbohydrate interaction. In vitro studies show that the intracellular carboxy terminal part can trigger a cascade of reactions resulting in the activation of transcription factor AP1. ${ }^{9}$ A heterotrimeric G-protein activation sequence in the intracellular carboxy terminal part, which can bind to $G_{\mathrm{o}} / \mathrm{G}_{\mathrm{i}}$, suggests that polycystin-1 may function as a heterotrimeric G-protein coupled receptor involved in signal transduction. ${ }^{10}$ A putative coiled-coil domain at the carboxy terminal part of the polycystin- 1 can bind to the carboxy terminus of polycystin-2, a protein encoded by the second $A D P K D$ gene. ${ }^{11,12}$ This gene, PKD2, located on chromosome band 4q22-q23, ${ }^{13,14}$ encodes a putative 968 amino acid protein and is predicted to have an internal amino terminus, six transmembrane domains and an internal carboxy terminus with a calcium binding structure (EF-hand domain). ${ }^{2}$ Polycystin-2 shows significant homology to polycystin- 1 and to the pore forming units of a number of cation channels. $^{2,15}$ Furthermore, association of polycystin-2 with the transient receptor potential channel 1 (TRPC1) protein has been reported, suggesting a role in ion transport. ${ }^{15}$

ADPKD is a commonly inherited renal disease which is characterised by the formation of fluid-filled cysts in the kidneys. ${ }^{16}$ About half the ADPKD patients suffer from end-stage renal failure before the age of $60 .{ }^{17}$ Cysts can also develop in several other organs, such as the liver, spleen and pancreas. ${ }^{18-20}$ High blood pressure, aneurysms and heart valve abnormalities are additional complications of the disease. ${ }^{21,22}$ In most ADPKD patients a mutation in either the PKD1 or
$P K D 2$ gene is responsible for the disease. The majority of identified mutations in both genes leads to a premature translation stop, most likely resulting in truncation of the protein product. ${ }^{23-26}$ Data suggest that ADPKD is a recessive disease at cellular level. In both PKD1 and PKD2 patients, somatic mutations were found in a subset of cysts. ${ }^{27-29}$ Mouse models of both $P K D 1$ and $P K D 2$ support a second hit hypothesis as the cause of cyst formation in the kidneys. ${ }^{30-32}$

In addition to the ADPKD families linked to the $P K D 1$ or $P K D 2$ locus, a few families have been found which are not linked to either locus, suggesting that mutations in at least one additional gene can cause the disease. ${ }^{33,34}$ Because polycystin-1 and polycystin-2 are approximately $25 \%$ identical, we searched for possibly related genes by screening several databases for homologous sequences. Consequently, we identified one partial cDNA clone ${ }^{35}$ and two genomic sequences with homology on protein level to polycystin-1 and polycystin-2. Here we describe the isolation of one novel gene, $P K D 2 L 2$, and confirm and extend the findings of two recently published genes, $P K D 2 L^{36,37}$ and PKDREJ. ${ }^{38}$

\section{Materials and Methods}

\section{Databases}

Blast searches of the human database of The Institute for Genomic Research (TIGR; http://www.tigr.org/index.html) and the nr (non-redundant), dbest (expressed sequence tag sites) and htgs (high throughput genomic sequences) databases of the National Center for Biotechnology Information (NCBI; http://www.ncbi.nlm.nih.gov) were performed using the DNA and protein sequences of both the PKD1 gene (GenBank L33243) and the PKD2 gene (GenBank U50928). Sequence data were obtained from the Sanger center (GenBank Z93024, Z79998, AL031034, AL031002 and AC004820), the DOE Joint Genome Institute (GenBank AC006084) and NCBI dbest database (GenBank W27963 and W28231). Alignments of the proteins were performed using clustalW1.7 (http://dot.imgen.bcm.tmc.edu:9331/multi-align/ multi-align.html) and boxshade3.21 (http://www.isrec.isbsib.ch/software/BOX_form.html). The prediction of the transmembrane helices was performed with TMpred (http://www.isrec.isb-sib.ch/software.html), SOSUI (http:/ /www.taut.ac.jp), PSORT program (http://psort.nibb.ac.jp.8800) and predict protein (http://www.embl-heidelberg.de). Coils 2.2 (http://www.isrec.isb-sib.ch/software.html; window 28; MTK matrix) was used for the prediction of coiled-coil structures in the novel gene products. ${ }^{39,40}$ To predict protein domains, the Pfam database (http:/ /www.sanger.ac.uk/pfam), the Prodom database (http://protein.toulouse.inra/fr/prodom.html), the Prints-Prosite scanner (http://www.biochem.ucl.ac.uk/cgi-bin/attwood/SearchPrintsForm2.pl), and a Profile scan (http://www.isrec.isb-sib.ch/ software/PFSCAN_form.html/) were used. 


\section{3' and 5' RACE}

A $3^{\prime}$ and $5^{\prime}$ rapid amplification of cDNA ends (RACE) was performed on approximately $0.05 \mathrm{ng}$ Marathon-ready cDNA (Clontech, Palo Alto, CA, USA) of human foetal brain, human foetal kidney and human testis using 5 pmol genespecific forward or reverse primer and 5 pmol primer AP1. Primers AP1 and AP2 (Clontech, Palo Alto, CA, USA) anneal to marathon adaptor sequences, located on both ends of the Marathon-ready cDNAs. Gene-specific primers were used for the RACE of both PKD2L and PKD2L2 (see Results, Table 3 ). The PCR was performed in long-range pH 8.9 buffer (100 mm Tris- $\mathrm{HCl}, \mathrm{pH} 8.9 ; 500 \mathrm{~mm} \mathrm{KCl}, 2 \mathrm{mg} / \mathrm{ml}$ BSA, $0.1 \%$ gelatin and $1.5 \mathrm{~mm} \mathrm{MgCl}_{2}$ ) with $0.2 \mathrm{~mm}$ dNTPs. After denaturing the samples for $2 \mathrm{~min}$ at $94^{\circ} \mathrm{C}$, a mix of 2.4 units amplitaq polymerase and 0.07 units $\mathrm{Pfu}$ polymerase was added at $90^{\circ} \mathrm{C}$ followed by 40 cycles of $10 \mathrm{~s}$ at $94^{\circ} \mathrm{C}, 10 \mathrm{~s}$ at $65^{\circ} \mathrm{C}$ and $4 \mathrm{~min}$ at $72^{\circ} \mathrm{C}$. A booster PCR of 35 cycles was performed on $5 \mu \mathrm{l}$ of a $1 / 10$ dilution of the PCR products in the same conditions as described above, using a gene-specific forward primer and semi-nested primer AP2.

The RACE products of $P K D 2 L$ were cloned in the pGEM T-easy vector (Promega, Madison, WI, USA). The cloned fragments and PCR products were sequenced using an ABI 377 (fluorescent) sequencer. We used the Perkin-Elmer Big Dye Terminator Cycle Sequencing Kit in combination with a gene-specific primer, primer AP2, a M13 master primer or a M13 reverse primer for sequencing.

\section{Mapping of PKD2L, PKD2L2 and PKDREJ}

The mapping of the $P K D 2 L$ gene was performed by fluorescence in situ hybridisation (FISH). We used a cloned RACE product of approximately $2 \mathrm{~kb}$ of the 3 ' end of the $P K D 2 L$ gene (primer F4 to poly A tail) as a probe (Table 3 ). A chromosome 10-specific library, pBS10 (kindly provided by Dr JW Gray, UCSF) was used for control staining. ${ }^{41}$ The probes were labelled separately by standard nick translation ${ }^{42}$ for the $P K D 2 L$ cDNA in the presence of digoxigenin11-dUTP (Roche Diagnostics, Almere, The Netherlands) and for the chromosome 10 -specific library, in the presence of biotin-14-dATP (Life Technologies, Breda, The Netherlands). Hybridisation, immuno-cytochemical detection and analysis of the slides was performed as described previously. ${ }^{43}$

Additionally, a Stanford G3 radiation hybrid panel (Research Genetics, Huntsville, AL, USA) was used for mapping the genes by genomic PCR using primers within the coding sequence of the genes and flanking at least one intron. For the $P K D 2 L$ gene, primers L1F5 and L1R4 and for the $P K D 2 L 2$ gene, primers L2F1 and L2R1 were used (Table 3). Since the PKDREJ gene is intronless, primers could not be chosen to discriminate between genomic and cDNA PCR products. Primers LF1 and LR1 were used for mapping of PKDREJ (Table 3). The PCR was performed as described for the RACE with an annealing temperature of $68^{\circ} \mathrm{C}(P K D 2 L)$, $55^{\circ} \mathrm{C}(P K D 2 L 2)$ and $63^{\circ} \mathrm{C}(P K D R E J)$. The Stanford website (http://www-shgc.stanford.edu/mapping/rh) was used for analysis of the results. For a precise mapping of $P K D 2 L$ and $P K D 2 L 2$, a genomic PCR on several yeast artificial chromosomes (YAC) of the CEPH mega-YAC library ${ }^{44}$ was performed. The localisations of the YACs were obtained from the chromosome 10 mapping group (http://www.cric.com/genesequences/index.html) and the Lovett lab homepage (http:/ /www.swmed.edu/home_pages/lovettlab/data.html). Analysis for $P K D 2 L$ was performed on YACs from contigs 59, 62 and
66 and for PKD2L2 on YACs 773d3, 880g9, 759d5, 737b9, $848 \mathrm{~d} 1$ and $748 \mathrm{~b} 8$.

\section{Northern Hybridisation and RT-PCR}

Multiple tissue northern blot human II (containing about $2 \mu \mathrm{g}$ poly $\mathrm{A}^{+}$RNA of spleen, thymus, prostate, testis, ovary, small intestine, colon and peripheral blood leukocytes), northern blot human foetal II (containing brain, lung, liver and kidney) and multiple tissue northern blot human 12-lane (containing brain, heart, skeletal muscle, colon, thymus, spleen, kidney, liver, small intestine, placenta, lung and peripheral blood leukocytes) (Clontech, Palo Alto, CA, USA) were hybridised for $90 \mathrm{~min}$ at $68^{\circ} \mathrm{C}$ in ExpressHyb hybridisation solution (Clontech) with ${ }^{32} \mathrm{P}-\alpha$-dCTP labelled cDNA probes. The probes were constructed by PCR on either testis or brain cDNA (Clontech) using PKD2L, PKD2L2 or PKDREJ specific primers (Table 3 ). Northern blot human II and human foetal II were hybridised with three PKD2L probes. The first probe was a testis cDNA $1287 \mathrm{bp}$ PCR fragment (primer L1F4 and L1R4), the second probe was a 671 bp testis cDNA 3' RACE product (primer L1F3 - poly A tail) and the third probe was a brain cDNA 3' RACE product (primer L1F3 poly A tail), which was 85 bp longer than the testis product due to alternative splicing. The human II, foetal II and human 12-lane northern blot were hybridised with a $1055 \mathrm{bp}$ testis cDNA probe of $P K D 2 L 2$ (primer $\mathrm{L} 2 \mathrm{~F} 3$ and $\mathrm{L} 2 \mathrm{R} 1$ ) and a 902 bp testis cDNA probe of PKD1L1 (primer LF1 and LF2), respectively, under the same conditions as described above. As a control both blots were hybridised with a human glyceraldehyde-3-phosphate dehydrogenase (GAPDH) probe.

Random-primed cDNA of several tissues (brain, spleen, pancreas, testis, thymus, heart, lung, retina, kidney and liver) was used to perform a reverse transcriptase PCR (RT-PCR) using $P K D 2 L$-specific primers L1F2 and L1R6 generating a $748 \mathrm{bp}$ (testis, retina and liver) or $833 \mathrm{bp}$ (brain and spleen) product (Table 3). Control RT-PCRs for PKD1 and PKD2 transcript were performed on the same samples using primers in exons 37 and 44 for $P K D 1$ and primers in exons 1 and 3 for $P K D 2$. PCR conditions as described for RACE with annealing temperatures of $65^{\circ} \mathrm{C}(P K D 2 L), 60^{\circ} \mathrm{C}(P K D 1)$ and $55^{\circ} \mathrm{C}$ (PKD2).

Random-primed cDNAs of human skeletal muscle (foetal and adult), placenta, lymphocytes, cortex, testis, foetal kidney, and foetal brain and cDNA of rhesus heart, liver and kidney were used for RT-PCR using PKD2L2 specific primers L2F3 and L2R1 in exon 3 and 8, generating a product of $1055 \mathrm{bp}$. PCR was performed as described for RACE with an annealing temperature of $52^{\circ} \mathrm{C}$.

\section{Results}

\section{PKD2L2 Gene}

With the aim of identifying sequences related to either the PKD1 or PKD2 gene, we searched in several databases for homologous sequences. Thus we identified the sequence of a genomic clone highly homologous to polycystin-2. This PAC clone DJ0038I10 (GenBank AC004820) on chromosome 5 was partially sequenced by the Sanger center. To obtain the complete 
cDNA sequence of the gene, specific primers were selected to perform a 3 ' and 5' RACE. Only the RACE on testis cDNA resulted in specific products. Sequencing of these RACE products yielded a cDNA with a total length of $2205 \mathrm{bp}$, which contained an open reading frame of $1839 \mathrm{bp}$, a $3^{\prime}$ untranslated region of $323 \mathrm{bp}$ and a poly-A signal. This novel gene, PKD2L2, encodes for a 613 amino acid protein (GenBank accession number AF118125). The gene product is approximately $48 \%$ identical and $67 \%$ similar to both polycystin-2 and the PKD2L protein (Figure 1, Table 1). At least two alternatively spliced products were obtained by 5' RACE on testis cDNA, but these fragments reveal additional exons, resulting in short open reading frames (data not shown). The significance of these spliced products is unclear.

During our analyses, the sequence of another PAC clone (9c13, LBNL H127, GenBank AC006084), sequenced by the DOE Joint Genome Institute (Lawr- ence Berkeley National Laboratory), became available. This clone contains the complete genomic sequence of PKD2L2. The intron-exon structure of the gene was determined and is shown in Table 2. The gene consists of 14 exons and covers about $51 \mathrm{~kb}$ of genomic DNA.

Genomic PCR on a whole genome radiation hybrid panel was performed to confirm the chromosome band 5q31 localisation of $P K D 2 L 2$. Primers flanking intron 7 of the gene were used. The highest lod score (9.0) was obtained with marker D5S500 (SHGC-11945). A refined localisation of the gene was obtained by PCR on a chromosome 5 YAC-contig around D5S500. Since only the PCR on YAC $848 \mathrm{~d} 1$ resulted in a product, we could map PKD2L2 between markers D5S479 and D5S414 (Figure 2).

Expression of the $P K D 2 L 2$ gene was only observed in testis by both RT-PCR and northern blot analysis. PCR on several cDNAs with a forward primer in exon 3 and a reverse primer in exon 8 resulted in a $1055 \mathrm{bp}$

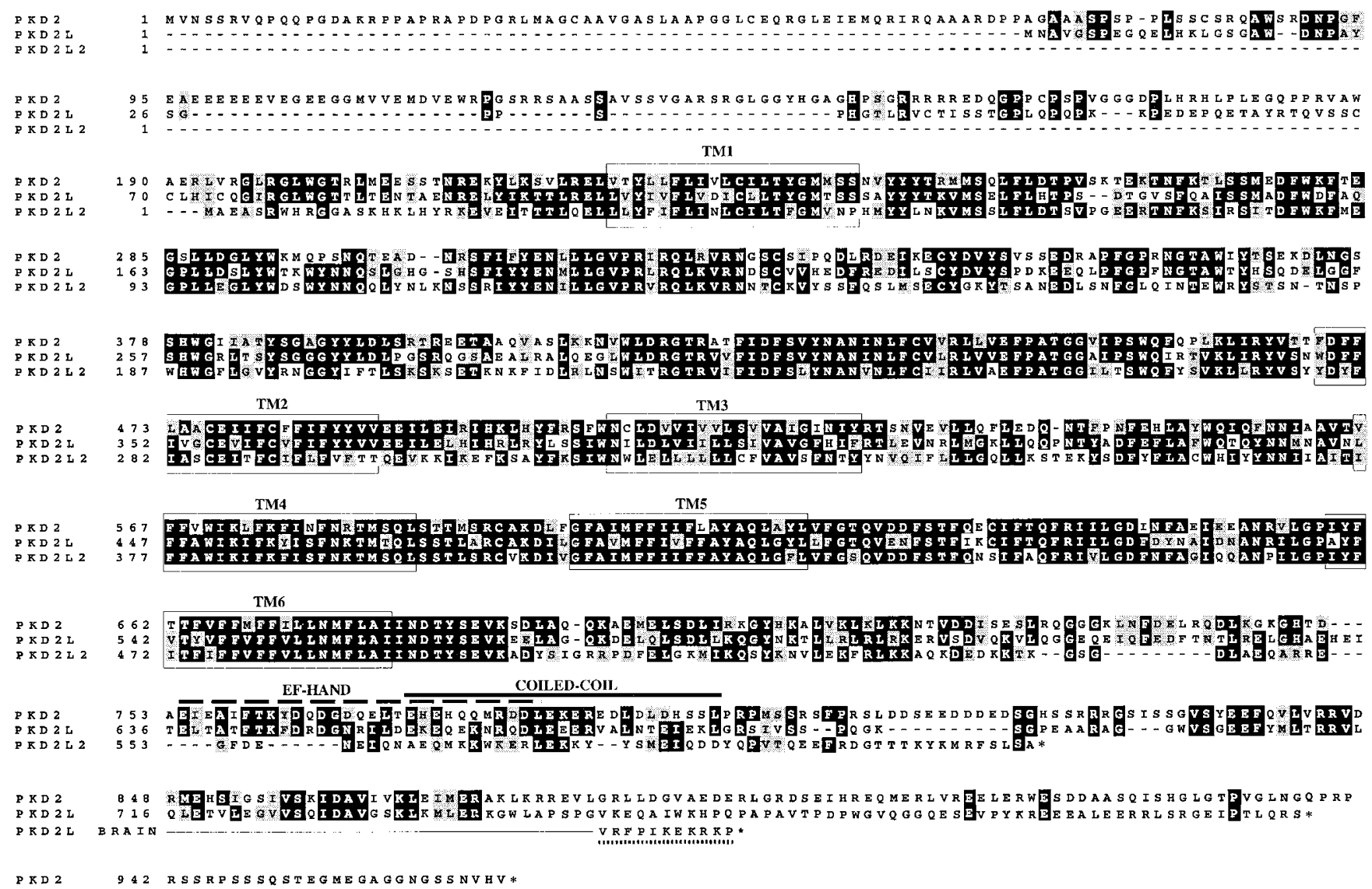

Figure 1 Comparison between polycystin-2 (PKD2, GenBank U50928), the PKD2-like protein ${ }^{37}$ (PKD2L, GenBank AF53316/AF094827) and the PKD2-like 2 protein (PKD2L2, GenBank AF118125). ClustalW1.7 and Boxshade 3.21 were used for amino acid sequence alignment. Black and grey indicate amino acid identities and similarities, respectively. The carboxy terminal ends of the proteins are indicated by an asterisk. The PKD2L amino acid sequence differs in brain and spleen compared with testis due to alternative splicing and is underlined. The predicted transmembrane domains (TM 1-6), EF-hand domain and coiled-coil domain are indicated 
Table 1 Homology between the protein products of the human PKD1, PKD2, PKDREJ, PKD2L, PKD2L2 and SuREJ genes. Each row indicates the amino acid position, the percentage of identity and the percentage of similarity (in italics) of the proteins in the left column, compared with the proteins in the top row. There is no homology between the proteins encoded by SuREJ and $P K D 2$ and its paralogues. See Figure 5

\begin{tabular}{|c|c|c|c|c|c|c|}
\hline & PKD1 & PKDREJ & PKD2 & PKD2L & PKD2L2 & REJ \\
\hline PKD1 & $\begin{array}{l}1-4302 \\
100 \% \\
100 \%\end{array}$ & $\begin{array}{l}1950-4139 \\
21 \% \\
36 \%\end{array}$ & $\begin{array}{l}3655-4139 \\
23 \% \\
43 \%\end{array}$ & $\begin{array}{l}3662-4138 \\
25 \% \\
43 \%\end{array}$ & $\begin{array}{l}3657-4138 \\
21 \% \\
41 \%\end{array}$ & $\begin{array}{l}1954-3109 \\
18 \% \\
35 \%\end{array}$ \\
\hline PKDREJ & $\begin{array}{l}6-2224 \\
20 \% \\
36 \%\end{array}$ & $\begin{array}{l}1-2253 \\
100 \% \\
100 \%\end{array}$ & $\begin{array}{l}1702-2250 \\
18 \% \\
40 \%\end{array}$ & $\begin{array}{l}1682-2239 \\
22 \% \\
39 \%\end{array}$ & $\begin{array}{l}1684-2239 \\
19 \% \\
36 \%\end{array}$ & $\begin{array}{l}7-1219 \\
17 \% \\
35 \%\end{array}$ \\
\hline PKD2 & $\begin{array}{l}206-714 \\
21 \% \\
41 \%\end{array}$ & $\begin{array}{l}213-762 \\
18 \% \\
40 \%\end{array}$ & $\begin{array}{l}1-968 \\
100 \% \\
100 \%\end{array}$ & $\begin{array}{l}192-872 \\
43 \% \\
64 \%\end{array}$ & $\begin{array}{l}198-801 \\
46 \% \\
66 \%\end{array}$ & XXX \\
\hline PKD2L & $\begin{array}{l}92-596 \\
23 \% \\
40 \%\end{array}$ & $\begin{array}{l}75-655 \\
21 \% \\
37 \%\end{array}$ & $\begin{array}{l}72-740 \\
44 \% \\
65 \%\end{array}$ & $\begin{array}{l}1-805 \\
100 \% \\
100 \%\end{array}$ & $\begin{array}{l}78-683 \\
46 \% \\
64 \%\end{array}$ & $\mathrm{xxx}$ \\
\hline PKD2L2 & $\begin{array}{l}16-528 \\
20 \% \\
38 \%\end{array}$ & $\begin{array}{l}6-575 \\
19 \% \\
36 \%\end{array}$ & $\begin{array}{l}6-589 \\
48 \% \\
68 \%\end{array}$ & $\begin{array}{l}6-588 \\
48 \% \\
67 \%\end{array}$ & $\begin{array}{l}1-613 \\
100 \% \\
100 \%\end{array}$ & $\mathrm{xxx}$ \\
\hline REJ & $\begin{array}{l}289-1449 \\
18 \% \\
35 \%\end{array}$ & $\begin{array}{l}265-1449 \\
18 \% \\
36 \%\end{array}$ & $\mathrm{xxx}$ & $\mathrm{xxx}$ & $\mathrm{xxx}$ & $\begin{array}{l}1-1450 \\
100 \% \\
100 \%\end{array}$ \\
\hline
\end{tabular}

fragment in testis cDNA, but no product was seen in the other tissues (data not shown). The 1055 bp PCR product was used as a probe to hybridise adult and foetal northern blots. Four transcripts ranging from $1.2 \mathrm{~kb}$ to $2.5 \mathrm{~kb}$ were seen in testis, but not in the other tissues tested (Figure 3c). No expression of PKD2L2 was found on a foetal northern blot (data not shown).

Table 2 Intron-exon structure of PKD2L2 gene on chromosome 5. The first exon contains a translation start site (ATG) and exon 14 contains a translation stop site (TAA). The sizes of the exons and introns and their positions in PAC clone 9c13 (GenBank AC006084) are shown. Start codon at position 29827; stop codon at position 80449 of the genomic sequence

\begin{tabular}{clcclr}
\hline Exon & $\begin{array}{l}\text { Position } \\
\text { AC006084 }\end{array}$ & $\begin{array}{l}\text { Size } \\
(\mathrm{bp})\end{array}$ & $\begin{array}{l}\text { Intron } \\
\text { Position } \\
\text { AC006084 }\end{array}$ & $\begin{array}{r}\text { Size } \\
(\mathrm{bp})\end{array}$ \\
\hline 1 & $29804-29857$ & $(31)$ & 1 & $29858-30815$ & 958 \\
2 & $30816-30917$ & 102 & 2 & $30918-32814$ & 1897 \\
3 & $32815-32948$ & 134 & 3 & $32949-34687$ & 1739 \\
4 & $34688-34944$ & 257 & 4 & $34945-39850$ & 4906 \\
5 & $39851-40072$ & 222 & 5 & $40073-46539$ & 6467 \\
6 & $46540-46768$ & 229 & 6 & $46769-48075$ & 1307 \\
7 & $48076-48246$ & 171 & 7 & $48247-49098$ & 852 \\
8 & $49099-49280$ & 182 & 8 & $49281-61929$ & 12649 \\
9 & $61930-62050$ & 121 & 9 & $62051-63714$ & 1664 \\
10 & $63715-63816$ & 102 & 10 & $63817-65334$ & 1518 \\
11 & $65335-65399$ & 65 & 11 & $65400-66169$ & 770 \\
12 & $66170-66224$ & 55 & 12 & $66225-76100$ & 9876 \\
13 & $76101-76213$ & 113 & 13 & $76214-80393$ & 4180 \\
14 & $80394-80771$ & 378 & 14 & & \\
\hline
\end{tabular}

The secondary structure was predicted using several programs. Like $P K D 2, P K D 2 L 2$ is predicted to have 6-8 transmembrane domains. The hydropathy plot of $P K D 2 L 2$ is shown in Figure 4f. The protein contains a cation channel TRPL motif (amino acids 242-494), a cation channel TM motif (amino acids 291-494) and a channel pore calcium-sodium motif (amino acids 373494). However, in contrast to PKD2, no putative EF-hand and coiled-coil domain were predicted (Figure 4e).

\section{PKD2L Gene}

Database searches also revealed the sequence of two complementary cDNA clones of $500 \mathrm{bp}$ (GenBank accession numbers W27963 and W28231) from a human retina cDNA sub-library with a remarkably high homology at the protein level to polycystin-2. In order to obtain the rest of the transcript, specific primers were designed (primer L1F2 and L1R3, Table 3) to perform a 3 ' and 5' RACE on testis, foetal brain and foetal kidney Marathon-ready cDNA. A testis cDNA sequence of 2541 bp was obtained which contains a translation stop codon and a poly-A signal but which lacks the 5 ' end of the transcript. This partial cDNA has an open reading frame of $2290 \mathrm{bp}$ encoding for 763 amino acids with an identity of $53 \%$ and a similarity of $67 \%$ to polycystin-2 (GenBank accession number AF053316) (Figure 1). 

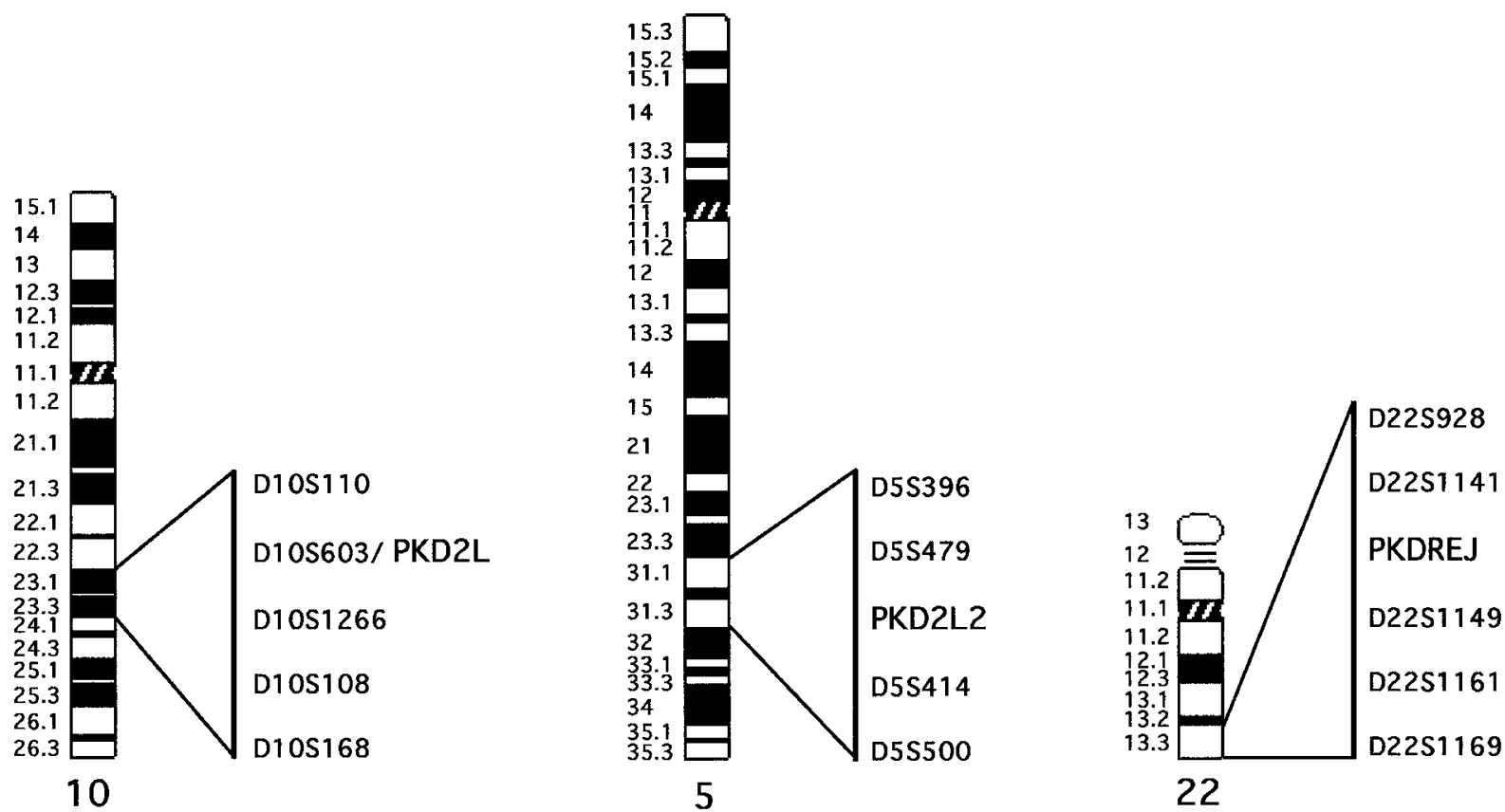

Figure 2 Localisation of the PKD2L, PKD2L2 and PKDREJ genes on chromosome 10, 5 and 22, respectively. Polymorphic markers around the genes are indicated

The highest homology has been found in the region containing transmembrane domains 4,5 and $6(73 \%$ identity). Recently, a partial cDNA sequence (PKD2L, GenBank AF094827) $)^{36}$ and a protein sequence $(\mathrm{PKDL})^{37}$ of a polycystin-like gene have been reported, which are identical to the sequence we obtained for testis cDNA sequence. Using brain Marathon cDNA for a 3' RACE with primer L1F3 (Table 3), we obtained an alternatively spliced product with an additional $85 \mathrm{bp}$ compared with the testis cDNA sequence. This product resulted in a different and truncated carboxy terminal end of the protein (Figure 1). No RACE products were obtained using foetal kidney Marathon cDNA. By FISH and whole genome radiation hybrid mapping, we confirmed the localisation of this gene to chromosome band 10q23-q24 (data not shown). Analysis of the data using the Stanford radiation hybrid mapping website revealed that the gene was linked to marker SHGC-17231 on chromosome 10 with a lod score of 9.5. Marker SHGC-17231 has been mapped between D10S574 and D10S603. A refined localisation of $P K D 2 L$ was obtained by PCR on a contig consisting of CEPH megaYACs 845h7, 904h9, 846g1, 723a1, $963 \mathrm{c} 11,912 \mathrm{c} 1$ and $751 \mathrm{~b} 2$, all containing the polymorphic marker D10S603. Further analysis revealed that the CA-repeat of marker D10S603 is actually located within an intron of the gene, and that the reverse primer of this marker is located within the coding sequence of $P K D 2 L$ (Figure 2).

To investigate the expression pattern of the gene and the length of its transcript, an adult and foetal northern blot were hybridised with $P K D 2 L$ specific probes. On the adult northern blot only a small transcript of less than $1.35 \mathrm{~kb}$ in thymus was detected (data not shown). No clear signal could be obtained for the other tissues. Hybridisation of a foetal northern blot resulted in a transcript in brain of approximately $6 \mathrm{~kb}$ (Figure 3a). No transcript was observed in foetal lung, liver or kidney. Expression of $P K D 2 L$ was also detected by means of non-quantitative RT-PCR. A product was found in adult brain, spleen, liver and retina mRNA (data not shown). Both brain and spleen showed the alternatively spliced product as described above. As a control we performed RT-PCR with PKD1 and PKD2specific primers. A transcript was found in all tissues tested, with the exception of retina mRNA (data not shown).

Several programs were used to predict the secondary structure and domains within the PKD2L protein. Like PKD2, PKD2L is predicted to have 6-8 transmembrane regions with internal amino- and carboxy termini. The hydropathy plot for the PKD2L protein is shown in 

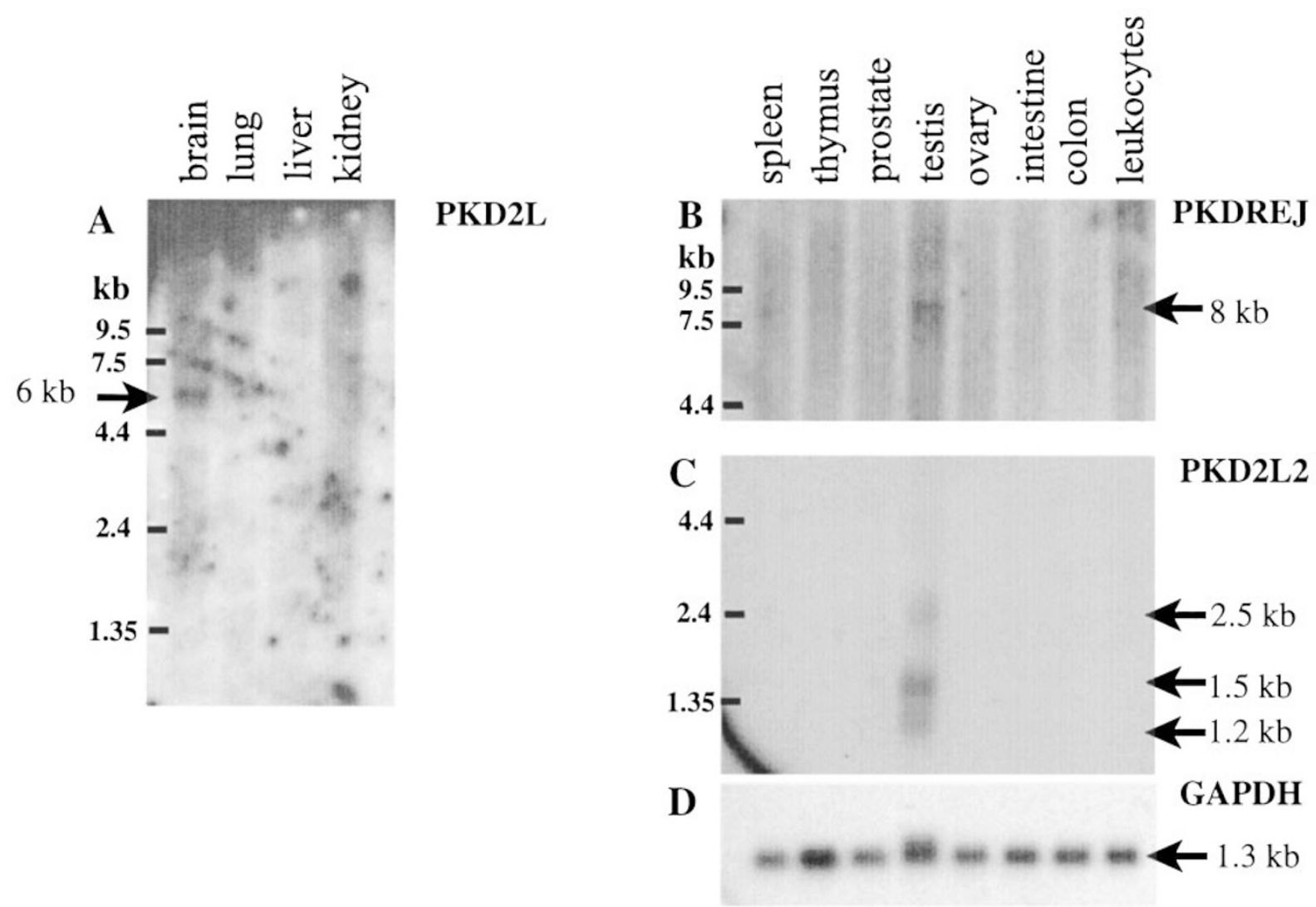

Figure 3 Expression of the PKD2L, PKD2L2 and PKDREJ gene on a foetal northern blot (panel $\mathbf{A})$ and adult northern blot (panels $\mathbf{B}$ and $\boldsymbol{C}$ ) containing approximately $2 \mu \mathrm{g}$ poly $A^{+} R N A$. A PKD2L expression using three probes: a $5^{\prime}$ testis cDNA probe (position 225-1512), a 3' testis RACE product (position 1787-poly A tail) and a 3' brain RACE product (position 1787-poly A tail). $\boldsymbol{B}$ PKDREJ expression using a testis cDNA probe (position 1010-1911). C PKD2L2 expression using a testis cDNA probe (position 227-1281). D GAPDH expression used as a control

Figure 4d. Part of the cytoplasmic carboxy terminal region of PKD2L (amino acids 637-665) shows resemblance to an EF hand domain (ELTATGTKFDRDGNRILDEKEQEKMRQDL) (Figure 1). This helix-loophelix structure can be involved in the binding of calcium and was also predicted to be in polycystin-2. ${ }^{2}$ Furthermore, a strong probability for a coiled-coil domain in the carboxy terminus was obtained (Figure 1, amino acids 652-686) using the Coils 2.2 program (window 28; MTK matrix) (Figure 4c). A weaker coiled-coil domain was predicted between amino acid positions 714 and 741 . In addition to its similarity to polycystin-2, the PKD2L protein also shows homology to the voltage activated calcium channels. Using the profile scan of the Swiss Institute for Experimental Cancer Research (ISREC) and the Sanger database of alignments and HMMs (pfam), three different cation channel motifs were predicted. The transient receptor potential subtype (TRPL) motif (amino acids 312-564, entry PS50272), the six transmembrane (TM) region, non-ligand gated motif (amino acids 361-564, entry PS50266), and a calcium and sodium channel pore region S4-S6 (amino acids 443-564, entry PS 629-657). These motifs are also predicted for polycystin- 2 .

\section{PKDREJ Gene}

Database searches with both polycystin-1 and polycystin-2 also revealed homology with three cosmids on chromosome 22. These cosmids, N5H6 (GenBank Z93024), B5E3 (GenBank Z79998) and N98G1 (GenBank AL031034 and AL031002), sequenced by the Sanger center, contain an open reading frame without introns of $6.7 \mathrm{~kb}$, which encodes for a putative 2253 amino acid protein. This deduced protein not only shows homology to both polycystin- 1 and polycystin-2, but also to the sea urchin receptor for egg jelly $(\mathrm{SuREJ})^{8}$ protein (Table 1). Recently, this gene has been described by Hughes et al and designated PKDREJ. ${ }^{38}$ Although the homology is not very high, the relationship between this protein and polycystin- 1 is 
A

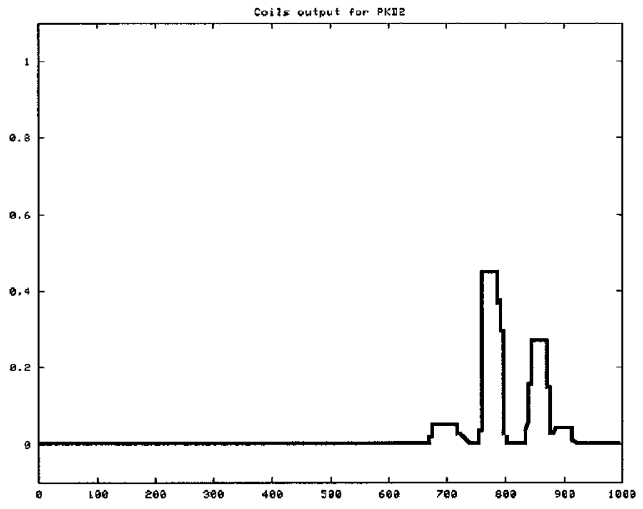

C

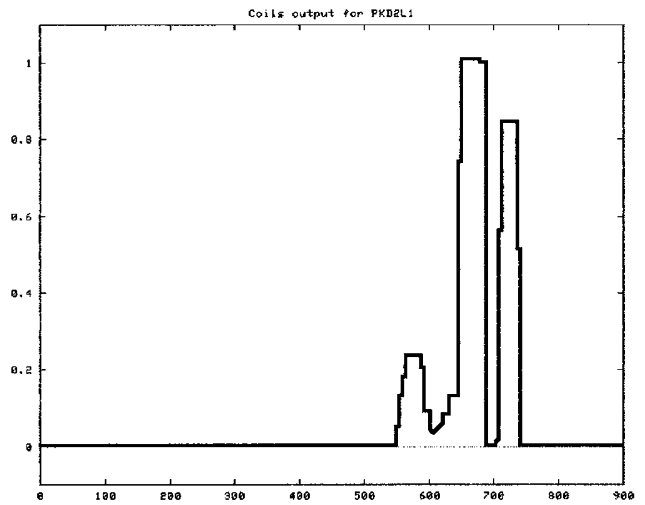

$E$

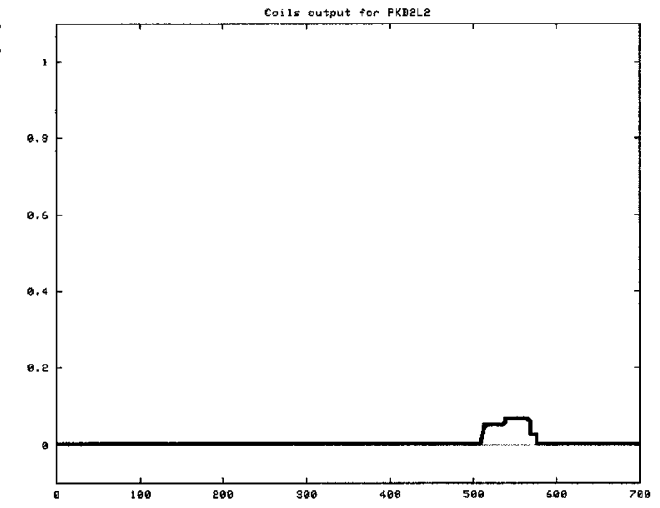

B
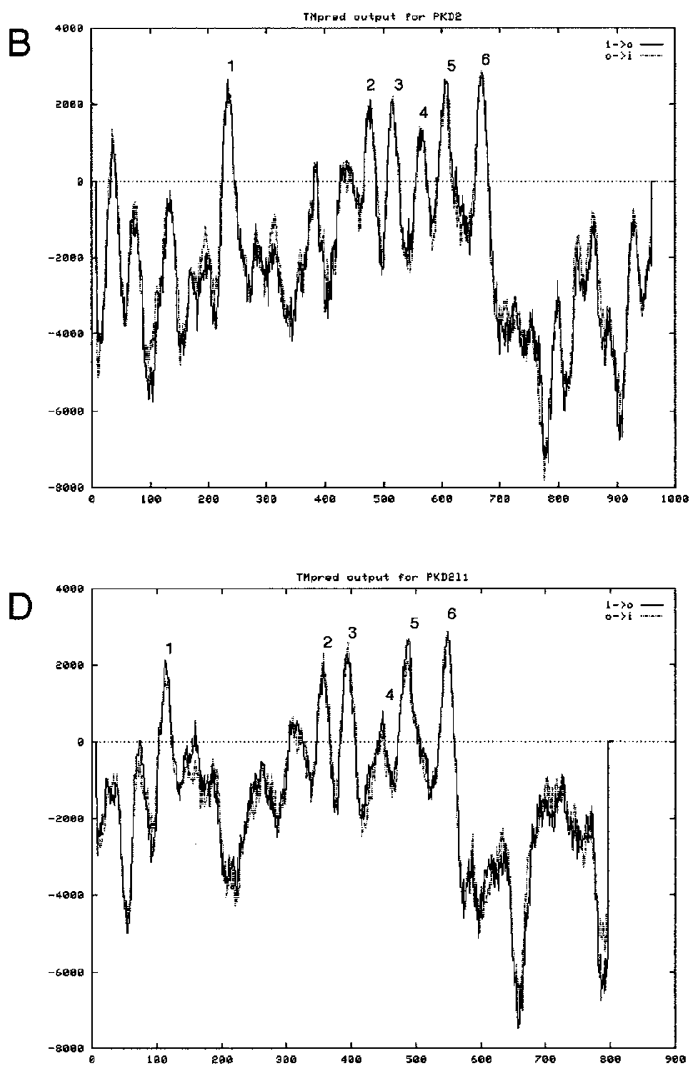

$\mathrm{F}$

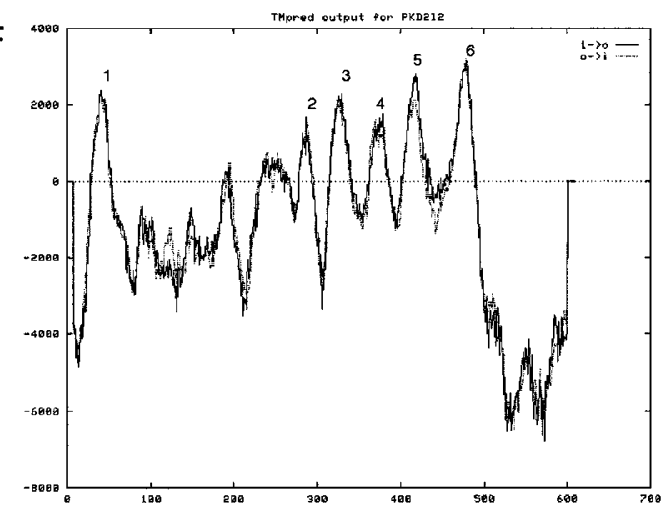

Hydropathy plot

PKD2

PKD2L

PKD2L2

Coiled-coil prediction

Figure 4 Predictions of the coiled-coil domains (panels $\boldsymbol{A}, \boldsymbol{C}$ and $\boldsymbol{E}$ ) using the Coils 2.2 program (window 28; MTK matrix) and the membrane-spanning regions (panel $\boldsymbol{B}, \boldsymbol{D}$ and $\boldsymbol{F}$ ) of the PKD2, PKD2L and PKD2L2 proteins. The hydropathy plots were constructed using the TMpredict program of Swiss Institute for Experimental Cancer Research

similar to that between polycystin-1 and polycystin-2 $(21 \%)$. In addition to the homology with polycystin-1, the amino-terminal half of the PKDREJ protein shows homology to the sea urchin REJ protein, whilst the carboxy terminal part shows homology to polycystin-2, PKD2L, and PKD2L2 (Figure 5, Table 1). To determine the length and expression pattern of the putative transcript, we hybridised northern blots containing foetal and adult tissues with a $900 \mathrm{bp}$ cDNA probe (primers LF1 and LF2). A transcript of approximately $8 \mathrm{~kb}$ was found only in testis, and not in other adult tissues tested (Figure 3b). No transcript could be 
Table 3 Primers used for $5^{\prime}$ and $3^{\prime}$ RACE, mapping and gene expression experiments of the PKD2L, PKD2L2 and $P K D R E J$ genes. The first coding nucleotide of the PKD2L2 and $P K D R E J^{38}$ genes have been designated position 1 (GenBank AF118125 and GenBank AF116458)

\begin{tabular}{lllr}
\hline \multicolumn{3}{l}{ Primer sequence } & Position $^{\text {a }}$ \\
\hline PKD2L & L1F2 & gccetgcctactttgtcaccta & 1485 \\
& L1F3 & ctcacggccaccttcaccaagtttgac & 1787 \\
L1F4 & tgacctatggaatgacaagctcc & 225 \\
L1F5 & tgctgtcaactcttcttcgcctgga & 1201 \\
L1F6 & ggcagctaaaggtccgcaatgact & 477 \\
L1R1 & acttggtgaaggtggccgt & 1808 \\
L1R3 & gtcaaacttggtgaaggtggccgtgag & 1813 \\
L1R4 & aagacataggtgacaaagtaggcagggc & 1512 \\
L1R6 & ctttgctccgggagtgcctcacacttaa & 2317 \\
L1R7 & tcacagccaacgataaagaagtccca & 942 \\
L1R9 & gatggcctgaaaggagactcca & 328 \\
PKD2L2 & L2F1 & tgtgtttgtggctgtttccttca & 977 \\
L2F2 & tttgcttatgcccagttaggatttcttg & 1255 \\
L2F3 & ccaactttaagtccattcgcag & 227 \\
L2F4 & cgcagagcagatgaaaaaatggaaagag & 1683 \\
L2F5 & catggctgaggcgtcacg & -1 \\
L2R1 & aagaaatcctaactgggcataagc & 1281 \\
L2R2 & gctgcgaatggacttaaagttggttc & 249 \\
L2R3 & ctttctgtaatgcaacttatgtttga & 63 \\
LF1 & aggcggtgatgcttggcgatgc & 1010 \\
LR1 & ccccttcctttctcctgttggt & 1911 \\
\hline
\end{tabular}

${ }^{\mathrm{a}}$ Since we lacked the $5^{\prime} \mathrm{DNA}$ sequence of the PKD2L gene, we designated the first base of the codon encoding a tyrosine at amino acid position 43 (Figure 1) as position 1. This position corresponds to the first position of GenBank accession number AF053316. detected on a foetal northern blot (data not shown). These data are in agreement with the expression pattern described by Hughes et al. ${ }^{38}$ To confirm the mapping of PKDREJ on chromosome 22 we performed a PCR on a whole genome radiation hybrid panel, generating a $900 \mathrm{bp}$ product. A lod score of 14.7 was obtained with marker SHGC-10573 on chromosome band 22q13.3. The localisation of the gene is shown in Figure 2. Prediction of the structure of the protein revealed 9-20 transmembrane domains, a lipoxygenase homology 2 region (LH2, amino acid positions 244-1339), a cation channel TRPL motif (transient receptor potential subtype, amino acid positions 1931-2175) and a cation channel TM motif (non-ligand gated, amino acid positions 1933-2175). A lipoxygenase homology 2 region was also predicted for polycystin-1 (amino acid positions 3132-3220).

\section{Homologies of the Paralogues}

The homologies of the three new members of the polycystin family were determined using ClustalW7.1 and Boxshade. The result is shown in Table 1 and Figure 5. The receptor for egg jelly in sea-urchin (SuREJ, GenBank U40832) is included in the table since it shows homology to both polycystin-1 and PKDREJ. No homology was found between SuREJ and polycystin-2 or its paralogues. For polycystin-2, PKD2L, and PKD2L2, the homology stretches over the membrane spanning regions of the proteins and a part

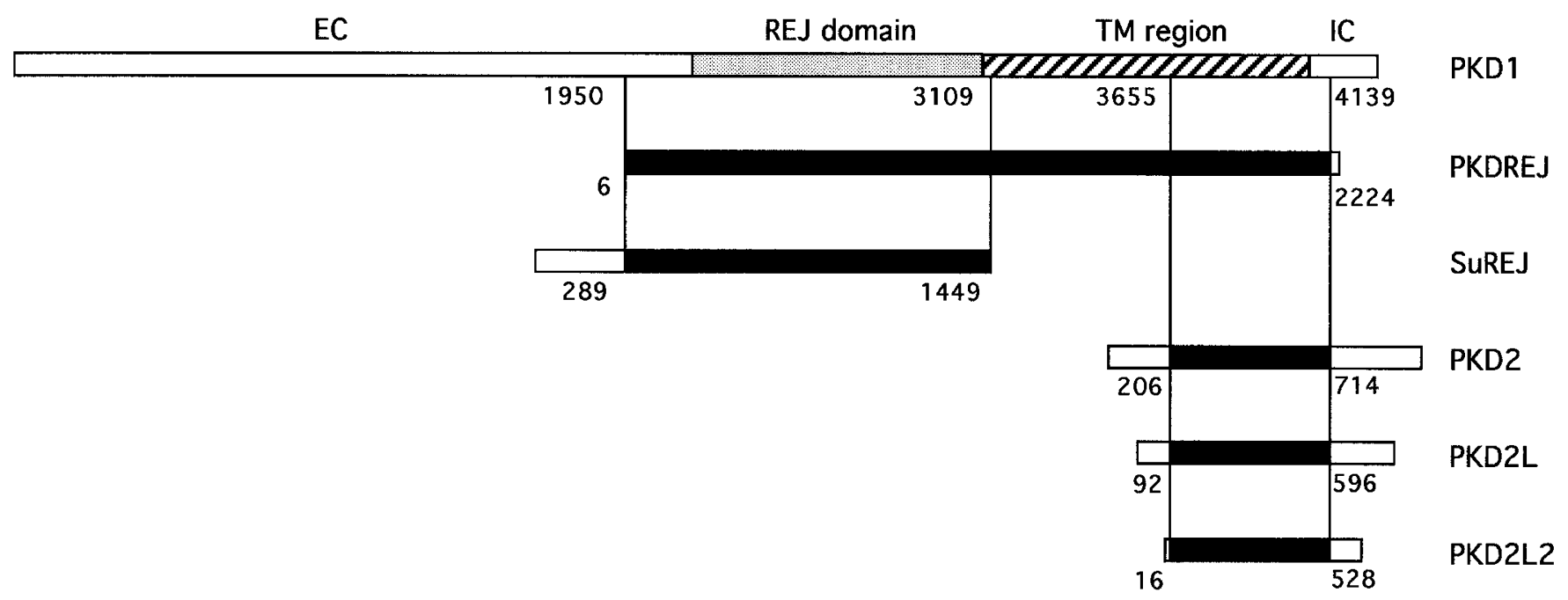

Figure 5 Regions of homology between polycystin-1 and the protein products of the PKD1L1, SuREJ, PKD2, PKD2L and PKD2L2 genes. Solid boxes illustrate the homologous sequences. The extracellular amino terminal region (EC), the REJ domain, the transmembrane spanning region (TM) and the intra-cellular carboxy terminal end (IC) of polycystin-1 are indicated. No homology between polycystin-2, the PKD2-paralogues and the sea urchin REJ protein has been found 
of the carboxy termini; however, both the aminoterminal and carboxy-terminal ends differ between the three proteins. The putative PKDREJ protein shows the highest score (163) to the SuREJ protein in a BLAST search, but the protein shows homology over its entire length with polycystin-1.

\section{Discussion}

The PKD1 and PKD2 gene products show significant homology to each other, and we therefore anticipated that the same would be true for the third PKD gene, which remains to be found. Looking for homology at the protein level, we have identified three genes. Two encode proteins which are highly homologous to polycystin-2 and the third encodes a protein which has significant homology to both polycystin-1 and 2. However, it seems unlikely that one of these genes is the third $P K D$ gene. We have mapped the genes in the genome and checked whether they are linked to the mutation in two Dutch families (PK5360; 8 meioses, 5 affected and $P K 5082 ; 22$ meioses, 6 affected), one Belgian family (PK5707; 12 meioses, 7 affected), and two Canadian families ${ }^{45}$ with ADPKD, which are not linked to either the $P K D 1$ or $P K D 2$ locus. We conclude that, using polymorphic CA-repeat markers (Figure 2) none of the three genes is responsible for ADPKD in these families (data not shown). This could mean that either the PKD3 gene product is not homologous to polycystin- 1 or -2 , or that the gene has not yet been sequenced and submitted to a database. In addition, we were also able to exclude linkage of these genes to polycystic liver disease in one family. ${ }^{46}$ Several mouse models with polycystic kidneys do not have defects linked to the syntenic regions of the new loci. ${ }^{47-53}$

Our search leaves us with the interesting result that there are three novel genes, the products of which show significant homology to polycystin-1 and 2. Two of them, the $P K D 2 L$ and $P K D 2 L 2$ gene products, have a remarkably high homology to each other and polycystin-2. The high homology suggests that these genes must be functionally related. Therefore it is interesting to determine how the expression patterns of these genes compare with the PKD2 gene.

Recently, two other groups reported the $P K D 2 L$ gene as a new member of the polycystin family, ${ }^{36,37}$ but no consensus was obtained about the expression pattern. Using probes covering the $5^{\prime}$ region $(1287 \mathrm{bp})$ and the 3 ' end of the gene (671 bp and $756 \mathrm{bp}$ ), we observed a transcript on a northern blot of approx- imately $6 \mathrm{~kb}$ in foetal brain. No transcript was detected in adult or other foetal tissues. Additionally, we observed expression in adult brain, spleen, retina, liver, testis and foetal brain by RT-PCR. Using a $1.5 \mathrm{~kb}$ cDNA probe covering the $5^{\prime}$ end of the coding sequence, largely overlapping with one of the probes described above, Nomura et al showed expression of PKD2L on a northern blot. ${ }^{37}$ Transcripts of $1.5 \mathrm{~kb}$ and $5.5 \mathrm{~kb}$ were seen in both foetal and adult tissues; however, in adult tissue the $1.5 \mathrm{~kb}$ transcript was predominant, and only after prolonged autoradiography a $5.5 \mathrm{~kb}$ transcript could be observed. In contrast, using a 198 bp cDNA probe from the middle part of the gene, located between the 5' and 3' probes described above, Wu et al showed transcripts of $2.4,2.7$ and $3.0 \mathrm{~kb}$ in several adult tissues. ${ }^{36}$ No transcripts were detected in foetal tissues. We do not have a satisfactory explanation for these different results generated by the three groups. Alternative splicing and cross-hybridisation with other transcripts are possible explanations.

Interestingly, using RT-PCR, expression of the PKD1 and $P K D 2$ genes was detected in all tissues investigated with the exception of retina, whereas $P K D 2 L$ is expressed in the retina. On a northern blot $\mathrm{Wu}$ et $a l^{36}$ showed expression of $P K D 2 L$ in the retina, which is in concordance with our data. It is conceivable that in the retina, $P K D 2 L$ is a functional homologue of the $P K D 2$ gene. Notably, one mouse mutant with a defect on chromosome 19, the syntenic region of human chromosome bands $10 \mathrm{q} 23-\mathrm{q} 24$, has been reported. ${ }^{54}$ This mouse model, $\mathrm{Krd}$, has a $7 \mathrm{cM}$ deletion around the pax2 gene and has kidney and retina defects. Nomura et $a l^{37}$ showed that $P K D 2 L$ is deleted in the $K r d$ mouse, but whether deletion of $P K D 2 L$ contributes to the symptoms remains to be seen. Patients with mutations in only the $P A X 2$ gene show both eye malformations and renal hypoplasia; ${ }^{55}$ thus the role of $P K D 2 L$ in the pathology of $\mathrm{Krd}$ mice is uncertain.

For PKD2L2 only a transcript in testis was detected by extensive northern blot analyses as well as by RT-PCR. The size of the largest observed transcript $(2.5 \mathrm{~kb})$ is consistent with an open reading frame of $1839 \mathrm{bp}$ and a 3 ' untranslated region of $323 \mathrm{bp}$. Several alternatively spliced variants were detected at the $5^{\prime}$ end of the gene, which could explain the smaller products. For these alternatively spliced products we did not observe large open reading frames.

There is apparent evidence that polycystin-1 and polycystin- 2 interact with each other. It would be most 
interesting to determine the interacting partners of the $P K D 2 L$ and $P K D 2 L 2$ gene products. Both $P K D 2 L$ and $P K D 2 L 2$ lack the homology to the region of polycystin2 which is involved in the interaction with polycystin1. ${ }^{11,12}$ However, using the Lupus algorithm, ${ }^{39,40}$ we found a strong probability for a coiled-coil domain in the C-terminus of the PKD2L protein, suggesting that this protein may interact with other proteins. For PKD2L2 no such region was predicted. A very weak coiled-coil domain was predicted for polycystin-2. ${ }^{11,12}$ This region is involved in the formation of homodimers, ${ }^{12}$ but has not yet been shown to be involved in binding to other proteins. Possibly the coiled-coil domain of PKD2L is also involved in homodimerisation or heterodimerisation with polycystin-like proteins. The predicted structures of PKD2 and the PKD2like proteins are similar, with 6-8 transmembrane domains and internal amino and carboxy termini. However, PKD2L2 lacks an EF-hand domain as predicted for PKD2 ${ }^{2}$ and PKD2L.

In addition to the paralogues of polycystin-2, we identified homology of both polycystin-1 and polycystin-2 with sequence of chromosome 22. A putative gene, PKDREJ, encoding for 2253 amino acids was extracted from the genomic sequence. It is striking that $P K D R E J$ is an intronless gene with a large open reading frame of $6759 \mathrm{bp}$. A transcript of approximately $8 \mathrm{~kb}$, corresponding to the expected size, was detected in testis on a northern blot. Consequently, we were able to exclude PKDREJ as a pseudogene, which is consistent with the data described by Hughes et al. ${ }^{38}$ The $\mathrm{N}$-terminal half of the protein shows homology to the SuREJ protein. The SuREJ protein, which is also homologous to a part of polycystin-1, is involved in triggering the acrosome reaction after binding to the egg jelly. ${ }^{8}$ In mice, Hughes et al showed expression of $P K D R E J$ in the testis from two weeks after birth to adult life, mirroring the production of mature spermatozoa. $^{38}$ These data suggest that PKDREJ is the human homologue of the sea urchin REJ protein, and may be involved in human fertilisation. However, there are several differences. The PKDREJ protein is larger than SuREJ and the structure resembles polycystin- 1 as opposed to SuREJ. In addition, several domains of SuREJ, such as the C-type lectin and EGF domain, are not present in PKDREJ. Furthermore the homology of PKDREJ with polycystin-1 extends over almost its entire length (2250 amino acid), whilst the homology with SuREJ extends only over the N-terminal half of PKDREJ. Further investigation of the possible inter- acting proteins and expression pattern is needed to elucidate the function of this protein.

The identification of a PKD1 paralogue on chromosome 22 seems to be in concordance with the data described by Giles et al. ${ }^{56}$ A large number of genes flanking the PKD1 gene on chromosome band $16 \mathrm{p} 13$ appear to have paralogues on chromosome bands 22q11-q13. The extent of the homologous area is approximately $12-14$ megabases. No PKD1 paralogue has yet been described on chromosome 22, but it is unlikely that $P K D R E J$ is the duplicate of the PKD1 gene. In most cases the identity between the paralogues on chromosomes 16 and 22 exceeds $50 \%$, but this is not the case for PKD1 and PKDREJ. Furthermore, $P K D R E J$ is half the size of $P K D 1$ and does not contain any introns. It seems likely that a retrotransposition event is responsible for the similarity between $P K D 1$ and $P K D R E J$. In addition to the cosmids containing the PKDREJ open reading frame, we identified a PAC clone on chromosome 22, dJ63G5 (GenBank Z94160), with homology to polycystin-1 (data not shown). Interestingly, this clone not only shows homology to polycystin-1, but also to tuberin-2, the protein encoded by $T S C 2$, a gene which flanks the PKD1 gene on chromosome 16. Although the homology to both proteins is rather low, this region on chromosome 22 may contain the paralogues of both the PKD1 and TSC2 genes. The identification of polycystin-1 and 2 paralogues is not surprising given the hypothesis that genome duplications have led to the increased number of genes, between invertebrates and vertebrates. ${ }^{57}$ During evolution copies of genes diverged, sometimes because of fusion to other genes. An altered regulation of gene expression enabled them to take new functional roles. For example, polycystin-1 and polycystin- 2 are widely expressed, ${ }^{1,2,58}$ whereas the paralogues have a restricted expression pattern. Interestingly, all genes are expressed in the testis, although it is unknown if they are expressed in the same cell types. Immunohistochemical staining should be performed to identify the exact temporal and physical localisation of these proteins. Elucidation of the expression pattern and function in testis may contribute to the understanding of the link between the polycystin family members, which probably have distinct but related functions. Like polycystin-2, PKD2L and PKD2L2 show homology to the voltage gated calcium/sodium channels and to the transient receptor potential (TRP) channels. ${ }^{2,15}$ It is conceivable that PKD2L and PKD2L2 may form (part of) a channel, as has been suggested for polycystin-2. 
The challenge for further research will be investigating what the differences and similarities between the PKD paralogues and PKD1 and PKD2 are as a means to understanding the function of all the members of this family of proteins.

\section{Acknowledgements}

This work was supported by funding from the Dutch Kidney Foundation grants C98.1527 and C95.1477. We wish to thank York Pei, Paul Coucke and Patrick Willems for providing patient material of 'unlinked' ADPKD families, Yves Pirson for material of the Polycystic Liver Disease family, Anneke den Hollander and Peter Heutink for hybridisation of cDNA libraries, and Ingrid Stec for sharing material and technical support. We also gratefully acknowledge Rachel Giles and Jeroen Roelfsema for helpful suggestions and the Genome Technology Center Leiden for sequencing of the transcripts and providing the genomic clones.

\section{References}

1 The European Polycystic Kidney Disease Consortium: The polycystic kidney disease 1 gene encodes a $14 \mathrm{~kb}$ transcript and lies within a duplicated region on chromosome 16. Cell 1994; 77: 881-894.

2 Mochizuki T, Wu G, Hayashi T et al: PKD2, a gene for polycystic kidney disease that encodes an integral membrane protein. Science 1996; 272: 1339-1342.

3 The American PKD1 Consortium: Analysis of the genomic sequence for the autosomal dominant polycystic kidney disease $(P K D 1)$ gene predicts the presence of a leucine-rich repeat. Hum Mol Genet 1995; 4: 575-582.

4 Hughes J, Ward CJ, Peral B et al: The polycystic kidney disease 1 (PKD1) gene encodes a novel protein with multiple cell recognition domains. Nat Genet 1995; 10: 151-159.

5 The International Polycystic Kidney Disease Consortium: Polycystic kidney disease: the complete structure of the PKD1 gene and its protein. Cell 1995; 81: 289-298.

6 Sandford R, Sgotto B, Aparicio S et al: Comparative analysis of the polycystic kidney disease 1 (PKD1) gene reveals an integral membrane glycoprotein with multiple evolutionary conserved domains. Hum Mol Genet 1997; 6: 1483-1489.

7 Bycroft M, Bateman A, Clarke $\mathrm{J}$ et al: The structure of a PKD domain from polycystin-1: implications for polycystic kidney disease. EMBO J 1999; 18: 297-305.

8 Moy GW, Mendoza LM, Schulz JR, Swanson WJ, Glabe CG, Vacquier VD: The sea urchin sperm receptor for egg jelly is a modular protein with extensive homology to the human polycystic kidney disease protein, PKD1. J Cell Biol 1996; 133: 809-817.

9 Arnould T, Kim E, Tsiokas L et al: The polycystic kidney disease 1 gene product mediates protein kinase $\mathrm{C}$ alphadependent and c-Jun N-terminal kinase-dependent activation of the transcription factor AP-1. J Biol Chem 1998; 273: 6013-6018.
10 Parnell SC, Magenheimer BS, Maser RL et al: The polycystic kidney disease-1 protein, polycystin-1, binds and activates heterotrimeric G-proteins in vitro. Biochem Biophys Res Commun 1998; 251: 625-631.

11 Qian FJ, Germino FJ, Cai Y, Zhang X, Somlo S, Germino GG: PKD1 interacts with PKD2 through a probable coiled-coil domain. Nat Genet 1997; 16: 179-183.

12 Tsiokas L, Kim E, Arnould T, Sukhatme VP, Walz G: Homo- and heterodimeric interactions between the gene products of PKD1 and PKD2. Proc Natl Acad Sci USA 1997; 94: 6965-6970.

13 Kimberling WJ, Kumar S, Gabow PA, Kenyon JB, Connolly CJ, Somlo S: Autosomal dominant polycystic kidney disease: localization of the second gene to chromosome 4q13-q23. Genomics 1993; 18: 467-472.

14 Peters DJM, Spruit L, Saris JJ et al: Chromosome 4 localization of a second gene for autosomal dominant polycystic kidney disease. Nat Genet 1993; 5: 359-362.

15 Tsiokas L, Arnould T, Zhu C, Kim E, Walz G, Sukhatme VP: Specific association of the gene product of $P K D 2$ with the TRPC1 channel. Proc Natl Acad Sci USA 1999; 96: 3934-3939.

16 Dalgaard OZ: Bilateral polycystic disease of the kidneys: a follow-up of two hundred and eighty four patients and their families. Acta Med Scand 1957; 328: 1-255.

17 Gabow PA: Autosomal dominant polycystic kidney disease. N Engl J Med 1993; 329: 332-342.

18 Milutinovic J, Fialkow PJ, Rudd TG, Agodoa LY, Phillips LA, Bryant JI: Liver cysts in patients with autosomal dominant polycystic kidney disease. Am J Med 1980; 68: 741-744.

19 Gabow PA, Johnson AM, Kaehny WD, Manco-Johnson ML, Duley IT, Everson GT: Risk factors for the development of hepatic cysts in autosomal dominant polycystic kidney disease. Hepatology 1990; 11: 1033-1037.

20 Torra R, Nicolau C, Badenas C et al: Ultrasonographic study of pancreatic cysts in autosomal dominant polycystic kidney disease. Clin Nephrol 1997; 47: 19-22.

21 Florijn KW, Saase van JLCM, Breuning MH, Chang PC: Autosomal dominant polycystic kidney disease and hypertension: a review. Contrib Nephrol 1992; 97: 71-92.

22 Chapman AB, Rubinstein D, Hughes R et al: Intracranial aneurysms in autosomal dominant polycystic kidney disease. N Engl J Med 1992; 327: 916-920.

23 Peral B, Gamble V, Strong C et al: Identification of mutations in the duplicated region of the polycystic kidney disease 1 (PKD1) gene by a novel approach. Am J Hum Genet 1997; 61: 1399-1410.

24 Roelfsema JH, Spruit L, Saris JJ et al: Mutation detection in the repeated part of the PKD1 gene. Am J Hum Genet 1997; 61: 1044-1052.

25 Veldhuisen B, Saris JJ, De Haij S et al: A spectrum of mutations in the second gene for autosomal dominant polycystic kidney disease (PKD2). Am J Hum Genet 1997; 61: $547-555$.

26 Viribay M, Hayashi T, Telleria D et al: Novel stop and frameshifting mutations in the autosomal dominant polycystic kidney disease 2 (PKD2) gene. Hum Genet 1997; 101: 229-234.

27 Qian FJ, Watnick TJ, Onuchic LF, Germino GG: The molecular basis of focal cyst formation in human autosomal dominant polycystic kidney disease. Cell 1996; 87: 979-987. 
28 Brasier JL, Henske EP: Loss of the polycystic kidney disease $(P K D 1)$ region of chromosome 16p13 in renal cyst cells supports a loss-of-function model for cyst pathogenesis. J Clin Invest 1997; 99: 194-199.

29 Koptides M, Hadjimichael C, Koupepidou P, Pierides A, Constantinou Deltas C: Germinal and somatic mutations in the PKD2 gene of renal cysts in autosomal dominant polycystic kidney disease. Hum Mol Genet 1999; 8: 509-513.

$30 \mathrm{Lu} \mathrm{W}$, Peissel B, Babakhanlou H et al: Perinatal lethality with kidney and pancreas defects, in mice with a targetted pkd1 mutation. Nat Genet 1997; 17: 179-181.

$31 \mathrm{Wu}$ G, D'Agati V, Cai Y et al: Somatic inactivation of $P k d 2$ results in polycystic kidney disease. Cell 1998; 93: 177-178.

$32 \mathrm{Lu} \mathrm{W,} \mathrm{Fan} \mathrm{X,} \mathrm{Basora} \mathrm{N} \mathrm{et} \mathrm{al:} \mathrm{Late} \mathrm{onset} \mathrm{of} \mathrm{renal} \mathrm{and}$ hepatic cysts in Pkd1-targeted heterozygotes. Nat Genet 1999; 21: 160-161.

33 Bogdanova N, Dworniczak B, Dragova D et al: Genetic heterogeneity of polycystic kidney disease in Bulgaria. Hum Genet 1995; 95: 645-650.

34 Daoust MC, Reynolds DM, Bichet DG, Somlo S: Evidence for a third genetic locus for autosomal dominant polycystic kidney disease. Genomics 1995; 25: 733-736.

35 Veldhuisen B, Dauwerse H, Coucke P, Breuning M, Peters D: A novel gene highly homologous to the autosomal dominant polycystic kidney disease 2 gene (PKD2). J Am Soc Nephrol 1998; 9: 384A.

$36 \mathrm{Wu}$ G, Hayashi T, Park JH et al: Identification of PKD2L, a human PKD2-related gene: tissue-specific expression and mapping to chromosome 10q25. Genomics 1998; 54: $564-568$.

37 Nomura H, Turco AE, Pei Y et al: Identification of PKDL, a novel polycystic kidney disease 2-like gene whose murine homologue is deleted in mice with kidney and retinal defects. J Biol Chem 1998; 273: 25967-25973.

38 Hughes J, Ward CJ, Aspinwall R, Butler R, Harris PC: Identification of a human homologue of the sea urchin receptor for egg jelly: a polycystic kidney disease-like protein. Hum Mol Genet 1999; 8: 543-549.

39 Lupas A, Van Dyke M, Stock J: Predicting coiled coils from protein sequences. Science 1991; 252: 1162-1164.

40 Lupas A: Prediction and analysis of coiled-coil structures. Methods Enzymol 1996; 266: 513-525.

41 Collins C, Wen Lin K, Segraves R, Fuscoe J, Pinkel D, Gray JW: Construction and characterization of plasmid libraries enriched in sequences from single human chromosomes. Genomics 1991; 11: 997-1006.

42 Langer PR, Waldrop AA, Ward DC: Enzymatic synthesis of biotin labeled polynucleotides: novel nucleic acid affinity probes. Proc Natl Acad Sci USA 1981; 78: 6633-6637.

43 Dauwerse JG, Jumelet EA, Wessels JW et al: Extensive cross-homology between the long and short arm of chromosome 16 may explain leukemic inversions and translocations. Blood 1992; 79: 1299-1304.
44 Cohen D, Chumakov I, Weissenbach J: A first-generation physical map of the human genome. Nature 1993; 366: 698-701.

45 Pei Y, He N, Wang KR et al: A spectrum of mutations in the polycystic kidney disease-2 (PKD2) gene from eight Canadian kindreds. J Am Soc Nephr 1998; 9: 1853-1860.

46 Pirson Y, Lannoy N, Peters DJM et al: Isolated polycystic liver disease as a distinct genetic disease, unlinked to PKD1 and PKD2. Hepatology 1996; 23: 249-252.

47 Davisson MT, Guay-Woodford LM, Harris HW, D'Eustachio P: The mouse polycystic kidney disease mutation (cpk) is located on proximal chromosome 12. Genomics 1991; 9: 778-781.

48 Takahashi H, Calvet JP, Dittemore-Hoover D, Yoshida K, Grantham JJ, Gatone VH: A hereditary model of slowly progressive polycystic kidney disease in the mouse. $J$ Am Soc Nephrol 1991; 1: 980-989.

49 Iakoubova OA, Dushkin H, Beier DR: Localization of a murine recessive polycystic kidney disease mutation and modifying loci that affect disease severity. Genomics 1995; 26: 107-114.

50 Flaherty L, Bryda EC, Collins D, Rudofsky U, Montogomery JC: New mouse model for polycystic kidney disease with both recessive and dominant gene effects. Kidney Int 1995; 47: 552-558.

51 Guay-Woodford LM, Bryda EC, Christine B et al: Evidence that two phenotypically distinct mouse PKD mutations, bpk and jcpk, are allelic. Kidney Int 1996; 50: $1158-1165$.

52 Janaswami PM, Birkenmeier EH, Cook SA, Rowe LB, Bronson RT, Davisson MT: Identification and genetic mapping of a new polycystic kidney disease on mouse chromosome 8. Genomics 1997; 40: 101-107.

53 Moyer JH, Lee-Tischler MJ, Kwon H-Y et al: Candidate gene associated with a mutation causing recessive polycystic kidney disease in mice. Science 1994; 264: 1329-1333.

54 Keller SA, Jones JM, Boyle A et al: Kidney and retinal defects (Krd), a transgene-induced mutation with a deletion of mouse chromosome 19 that includes the Pax2 locus. Genomics 1994; 23: 309-320.

55 Sanyanusin P, McNoe LA, Sullivan MJ, Weaver RG, Eccles MR: Mutation of $P A X 2$ in two siblings with renalcoloboma syndrome. Hum Mol Genet 1995; 4: 2183-2184.

56 Giles RH, Dauwerse JG, Van Ommen G-JB, Breuning MH: Do human chromosomal bands 16p13 and 22q11-13 share ancestral origins? Am J Hum Genet 1998; 63: $1240-1242$.

57 Nadeau JH, Sankoff D: Comparable rates of gene loss and functional divergence after genome duplications early in vertebrate evolution. Genetics 1997; 147: 1259-1266.

58 Peters DJM, Van de Wal A, Spruit L et al: Cellular localisation and tissue distribution of polycystin-1. $J$ Pathol 1999; 188: 439-446. 